\title{
An in-depth look at the Coalition of Immokalee Workers
}

\author{
Review by Becca Berkey* \\ Northeastern University
}

Review of I Am Not a Tractor! How Florida Farmworkers Took on the Fast Food Giants and Won, by Susan L. Marquis. (2017). Published by Cornell University Press. Available as hardcover and Kindle ebook; 296 pages. Publisher's website: http://www.cornellpress.cornell.edu/book/ $\underline{\text { ?GCOI }=80140100598130}$

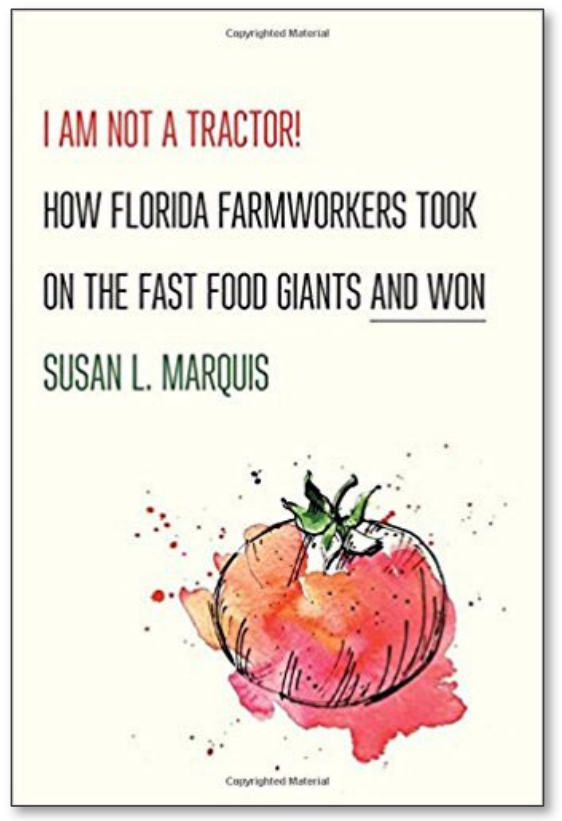

Submitted February 14, 2018 / Published online March 29, 2018

Citation: Berkey, B. (2018). An in-depth look at the Coalition of Immokalee Workers [Book review]. Journal of Agriculture, Food Systems, and Community Development, 8(1), 197-199. https://doi.org/10.5304/jafscd.2018.081.015

Copyright (C 2018 by the Author. Published by the Lyson Center for Civic Agriculture and Food Systems. Open access under CC BY license.

T you ask the average person what they know 1 about the people who labor on farms in the United States, you are likely to find that they have never given it much thought, or that if they have, they answer based on their notions of the agrarian

\footnotetext{
* Becca Berkey, $\mathrm{PhD}$, is director of Service-Learning and codirector of the Center of Community Service at Northeastern University in Boston, Massachusetts. In addition, she serves as associate director of the Northeastern Environmental Justice Research Collaborative. She has active projects and partnerships relating to environmental justice and farm labor, as well as faculty development in service-learning/community engagement work. Learn more at www.beccaberkey.com. She can be reached at r.berkey@,northeastern.edu.
}

ideal. Maybe, just maybe, you would find that they have some basic sense of the atrocities that most of the over two million farmworkers who harvest our food face. If they heard of these issues recently, they may have learned about them through the campaigns of the Coalition of Immokalee Workers (CIW). Whether through its community organizing efforts on college campuses; its work boycotting of some of the nation's largest fast food chains; through the documentary Food Chains (Longoria, Schlosser, \& Rawal, 2014); or its other educational, outreach, and campaign work, the CIW and its other entities have become a recognized name in farmworker justice. In I Am Not a Tractor! How 
Florida Farmworkers Took on the Fast Food Giants and Won, Susan L. Marquis details the history of CIW and of its Fair Food Program (FFP), as well as its possibilities for the future. I approached this book as someone who has been working with various farmworker and farmer justice groups for the past decade in my own teaching and research; although I have never worked directly with CIW in these or any other capacities, I was certainly familiar with their work.

In the opening paragraphs of the book, Marquis (who is both dean of the Pardee Rand School and vice president for the Rand Corporation) gives us a sense of who she is and how she came to be interested in CIW, as well as several key questions that framed her work for the book: (1) Why did the CIW think these corporate giants were the key to increasing farmworker pay or eliminating violence and abuse in the fields?, and (2) Was it really possible that farmworkers themselves, as a community, could successfully take on agricultural labor problems that have existed throughout the history of the U.S.? (p. 3). Also in her prologue, she covers in a few pages some history of labor in U.S. agriculture, including the legacy of slavery, convict leasing, and debt peonage, as well as the agricultural exceptionalism in many policies that protect workers, such as the National Labor Relations Act of 1935 and the Fair Labor Standards Act of 1938.

Marquis spent six years working with and getting to know the CIW, and it is clear throughout the book that she not only built strong relationships during that time, but also that she deeply admires the work, commitment, and passion of the staff members and affiliates of the CIW. Chapters 1 through 3 focus on the early years (the 1990s) and players in the CIW, deeply rooting their work in the philosophy and practice of centrally involving farmworkers themselves in all of their decisions and actions. It was in these early years, she states, that they settled on the rallying cry still reflected in their offices today of, "Todos somos lideres," or "we are all leaders." In these beginning phases of the CIW's formation, they started with questions around what was happening to farmworkers on the ground and how things got that way, to a more activist-centered approach examining what they could do about the terrible working conditions and injustices that farmworkers in the tomato fields of Immokalee faced. It was during these years that the CIW began to focus its energy on the market power of large corporations to influence the problematic practices exhibited by tomato growers, a strategy first developed and successfully implemented in the early 1980s by the Toledo, Ohio-based Farm Labor Organizing Committee in its boycott of Campbell's Soup Company (Serrin, 1984).

In Chapters 4 through 6, Marquis moves beyond the original victories won and celebrated by the CIW to dive more into where the rubber met the road in moving their work to the next level. First, she details a pivotal partnership - their relationship with Jon Esformes of Pacific Tomato growers, who, "in signing the Fair Food agreement...smashed through the decades-long, linkedarm resistance of the Florida tomato growers, providing the opening that brought down the dam and unleashed a transformation of Florida's tomato fields" (p. 96). From this moment it became clear that there was a business case that abuse of farmworkers was undermining the industry, Marquis reflects. Then, in Chapter 5 she moves on to discuss issues of compliance, enforcement, and accountability of the Fair Food agreement and how, in doing so, the organization decided it wanted a new approach (versus external audits) that linked standards, monitoring, and resolution. In the final chapter of this section, Marquis details how these early ideas became the Fair Food Standards Council (FFSC), as well as the council's current structure, components, and successes.

Chapters 7 through 9 focus more expansively on the evolving tactics and systems of the CIW and FFSC, the impact their work has made in the lives of farmworkers, and the insights that can be drawn from their success. In these final chapters of the book, Marquis continues to weave in the stories of the main people associated with, and who have shaped and are shaping, the work of CIW and the FFSC. She also focuses in on her assertion that the Fair Food Program has been "the only bright light" (p. 172) in helping prevent the abuses that farmworkers face. While she began the book with the two questions stated previously, she ends it by circling back to a question she poses in multiple 
variations, "so why has the CIW succeeded while many others have not?" (p. 196). She concludes with some of CIW's current new projects, like the establishment of the Worker-Driven Social Responsibility Network (WSR-N), some of the challenges they face in continuing their work as an organization, and reflections on how their work can continue to expand to other markets and geographical areas while still maintaining its integrity.

The memoir-like retelling of the current history of the CIW, FFP, FFSC, and their main players in this book is compelling, and represents a huge level of commitment and care on Marquis's behalf that is to be commended. However, particularly the last section of the book would present a stronger analysis by providing a critique of the work of CIW, situated within the larger body of literature detailing and documenting justice issues faced by farmworkers, as well as through an earnest look at both what other organizations and movements around farmworker justice have accomplished, rather than dismissing them outright. Even where she does bring in other programs, such as the Equitable Food Initiative (EFI) and the work of the Farm Labor Organizing Committee (FLOC), the mention is brief and only given as it relates to the work of CIW. There is a rich history and tradition of organizing around farmworker justice that is largely overlooked, and a reader with little previous knowledge of the field could walk away thinking that the CIW and its entities are the only hope-and I disagree with this position. Additionally, while the CIW's work has focused on important issues such as conditions in the fields, fair pay, and sexual harassment, there are other issues facing farmworkers such as pesticiderelated illness and death, treatment of and pathways for guestworkers in agriculture, immigration, community organizing, housing, local and state electoral politics, and many others that she does not comment on, or only does so in passing. Finally, while there have been many laudable successes, what are the drawbacks and compromises inherent in the CIW's model?

This book is a good entry point for people who are interested in labor in the food system and/or who want to be inspired by people working together to develop one set of potential approaches to reducing abuses for laborers on farms. To complement this book, and for a more expansive discussion of programs and their impacts on farmworker justice, also explore the work of the Fair Facts program of the Domestic Fair Trade Association (2015), as well as a report that Marquis references, published by the Fair World Project entitled Justice in the Fields (Lindgren, 2016). Additionally, researching other organizations engaged in this fight (in addition to those mentioned aboveUnited Farm Workers, Pineros y Campesinos Unidos del Noroeste, the Agricultural Justice Project, and the Farmworker Association of Florida, to name a few) would give the reader a better sense of the CIW's work that paved the way and continues today. To truly change the lives of all farmworkers in the United States, we need to recognize and hold up the good work being done in various places, so we can continue to learn with one another in the broader fight for justice. Marquis effectively tells the story of CIW's role in that larger, ongoing narrative.

\section{References}

Domestic Fair Trade Association. (2015). Simple comparative analysis: 2015: DFT A evaluation of fair trade and social justice certification claims. Retrieved from http:// fairfacts.thedfta.org/

Lindgren, K. (2016). Justice in the fields: A report on the role of farmworker justice certification and an evaluation of the effectiveness of seven labels. Retrieved from the Fair World Project website: http://fairworldproject.org/resources/certifieranalysis/farmworker-certification-analysis/

Longoria, E. (Producer), Schlosser, E. (Producer), \& Rawal, S. (Director). (2014). Food chains: The revolution in America's fields [Motion picture]. United States: Screen Media Films.

Serrin, W. (1984, July 2). Migrant workers organize a boycott of Campbell. The New York Times. Retrieved from http://www.nytimes.com/1984/07/02/us/migrant-workers-organize-a-boycott-of-campbell.html 